\title{
POLITIKK
}

SKANDINAVISK TIDSSKRIFT

FOR INTERNASIONALE STUDIER

Årgang 79, Nummer 4, side 388-410, 2021, ISSN 1891-1757, www.tidsskriftet-ip.no, Publisert november 2021

\section{Norsk støtte til FNs totalforbud mot atomvåpen?}

\author{
Torgeir E. Fjærtoft \\ Utenriksdepartementet, Norge*
}

\begin{abstract}
Sammendrag
FNs totalforbud mot atomvåpen er innlysende riktig. Forpliktelsene går neppe lenger enn Ikkespredningsavtalen, som Norge sluttet seg til allerede i 1970. Avskrekking med atomvåpen forutsetter at de må være klare til bruk for å bli umulige å bruke. Særlig i kriser blir en slik tankegang lett farlig fordi den kan utløse atomkrig ved misforståelser. Likevel er den norske regjeringens motstand mot FNs totalforbud rasjonell fordi hensikten er å forebygge en endring i oppfatning om maktbalanse som kunne undergrave Norges selvstendighet. Spørsmålet blir derfor om risiko for atomkrig kan reduseres uten å øke fare for press, og i verste fall angrep? Artikkelen presenterer egen forskning om hvordan konfrontasjonen i første halvdel av 1980-tallet mellom de to tyske stater førte til risiko for storkrig utløst av gjensidige misforståelser på begge sider av det daværende jernteppet. Teorier om tankeprosesser forklarer misforståelsene som universelle kognitive begrensninger. Forholdene i dag er på vesentlige punkter sammenliknbare med første halvdel av 1980-årene, da det på tross av spenninger likevel var rom for initiativ til felles sikkerhet. Artikkelen konkluderer derfor med at Norge bør slutte seg til FNs totalforbud mot atomvåpen, og sammen med Sverige ta initiativ til en felleseuropeisk dialog med Russland om en europeisk sikkerhetsordning bygd på forestillinger om felles sikkerhet.
\end{abstract}

Nøkkelord: atomvåpen $\cdot$ avskrekking $\cdot$ sikkerhet $\cdot$ dialog

^Denne artikkelen utrykker hans egne vurdering som forsker i hans prosjekt "Common Security".

Kontaktinformasjon: Torgeir E. Fjærtoft, e-post: tef@mfa.no, tef@commonsecurity.no

(C2021 Torgeir E. Fjærtoft. This is an Open Access article distributed under the terms of the Creative Commons Attribution 4.0 International License (https://creativecommons.org/licenses/BY/4.0/), allowing third parties to copy and redistribute the material in any medium or format and to remix, transform, and build upon the material for any purpose, even commercially, provided the original work is properly cited and states its license.

Citation: Fjartoft, T. E. (2021). Norsk støtte til FNs totalforbud mot atomvåpen? Internasjonal Politikk, 79(4), 388-410. http://dx.doi.org/10.23865/intpol.v79.3195 


\section{Innledning}

Norges nasjonale sikkerhet er en trygghet mot andre lands press og undergraving uten risiko for krig. Atomvåpen er derimot en stående trussel om undergang. Atomvåpenstrategier er tankekonstruksjoner som operasjonaliserer apokalypsen. Totalforbud mot atomvåpen er derfor innlysende fornuftig. Av gode grunner er det likevel politisk vanskelig.

Norges og andre NATO-alliertes motstand så langt mot FNs totalforbud dreier seg ikke om atomvåpen, men om forholdet til Russland; om et norsk forsvar mot et tenkelig russisk press, eller i verste fall militære angrep, er troverdig uten en kopling til USAs atomvåpenstrategi, den såkalte "atomparaplyen». USA motsetter seg at land med deres sikkerhetsgaranti forbyr atomvåpen.

Denne artikkelen vil derfor analysere om norsk tilslutning til FNs atomvåpenforbud, som i seg selv er innlysende fornuftig, vil undergrave norsk sikkerhet. For å vurdere dette spørsmålet, vil artikkelen først drøfte følgende:

1. Hvordan omsetter kognitive prosesser strategier til handling?

2. Hvordan og hvorfor har atomstrategier utviklet seg?

Deretter vil forfatteren presentere sine funn i sitt forskningsprosjekt om sikkerhetspolitisk tenkning i de to tyske stater i første halvdel av 1980-årene. Innsikt i denne farlige fasen av den kalde krigen er relevant for å utvikle en sikkerhetspolitikk som forebygger en sammenliknbar utvikling i forholdet til Russland i dag. Til slutt vil forfatteren vise hvordan Norge gjennom tilslutning til FNs totalforbud mot atomvåpen kan vinne støtte for forhandlinger om felles sikkerhet i Europa.

\section{Hvordan omsetter kognitive prosesser strategier til handling?}

Norge har levd i fred og frihet som USAs allierte i NATO under den amerikanske «atomparaplyen». Derfor avviser regjeringen FNs totalforbud mot atomvåpen. Våre analyser anvendt på sikkerhetspolitiske beslutninger er uunngåelig begrenset av våre historiske erfaringer, med Henry Kissingers ord, "the significance of a range of experience». Han mener svarene vi får ikke kan blir bedre enn spørsmålene vi stiller (Kissinger, 1973).

Det betyr at vi må kritisk prøve om vår forståelse av sikkerhetspolitiske problemer er relevant, om våre spørsmål til historien er de riktige (Jervis, 2017). Et eksempel viser dette. Fram til Cuba-krisen i 1962 var USAs planlegging for atomvåpen preget av erfaringene fra bombetoktene under andre verdenskrig (Bundy, 1988). Cuba-krisen overbeviste president Kennedy om at denne erfaringen ikke lenger var relevant. I stedet ble han opptatt av at første verdenskrig brøt ut som følge av sviktende krisehåndtering (Kennedy \& Schlesinger, 2011). Denne artikkel hevder, i tråd med Kissingers syn på historiske erfaringers relevans, at den pågående kalde krigen med Russland må forstås gjennom en sammenlikning med den kalde krigen i første halvdel av 1980-tallet. Det samme gjelder handlingsrommet selv under harde konfrontasjoner for å utvikle enighet om noen viktige prinsipper for felles sikkerhet. 
Forklaringen på hvordan vi i vår tenkning, også om atomvåpenstrategi, er begrenset av vår tolkning av tidligere hendelser, er den såkalte "slutningsstigen» (Senge, 1994). Her er en skjematisk framstilling, i engelsk versjon, «Ladder of Inference». ${ }^{1}$ Den viser hvordan vi alle utvikler vår egen sosiale og politiske virkelighet som en tolkning av tidligere hendelser, med mindre vi kritisk vurderer om våre slutninger er holdbare.

\section{LADDER OF INFERENCE}

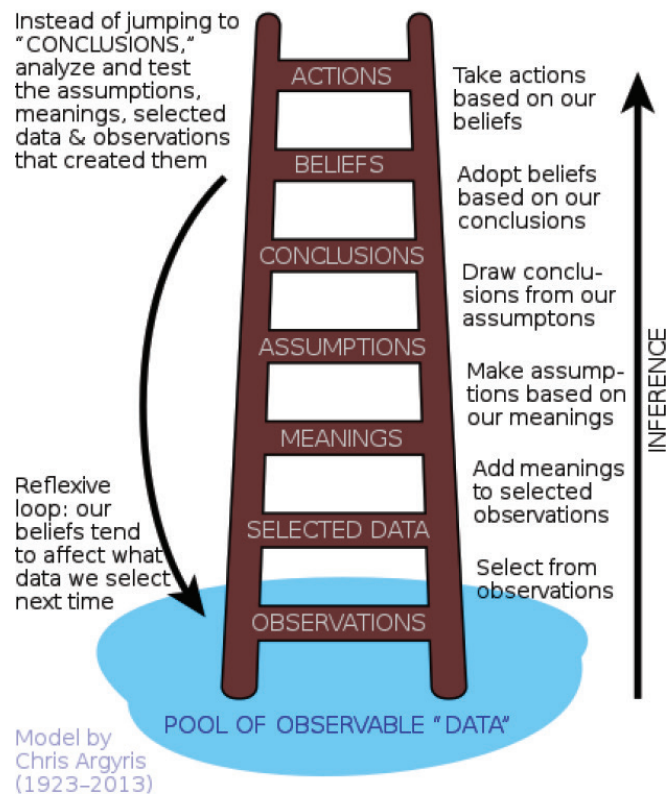

Slutningsstigen er en mental modell av virkeligheten som vi forholder oss til som om det var selve virkeligheten (Heuer, 1999). Vår mentale modell av den sosiale og politiske verden er imidlertid én blant flere. Det er det grunnleggende problem i sikkerhetspolitikk. Andres mentale modeller, ikke våre, styrer deres veivalg. Med mindre vi gjennom kritisk analyse unnslipper slutningsstigens selvbekreftende kretsløp, forblir vi fanget av våre antagelser. Det blir vår utfordring i å utvikle en rasjonell analyse som kan anvendes i sikkerhetspolitiske strategier.

Siden tilgjengelige data er uendelig, men vår evne til kognitiv analyse utilstrekkelig, blir vår rasjonelle tenkning begrenset, med det engelske uttrykket bounded rationality (Allison \& Zelikow, 1999; Kahneman, 2003; Simon, 2013). Allison og Zelikow, i sin analyse av Cuba-krisen i 1962, legger denne kognitive begrensning på rasjonalitet til grunn (Allison \& Zelikow, 1999). I tillegg viser de at organisasjoner, typisk militære, ytterligere begrenser rasjonalitet ved å innskrenke individuelt

\footnotetext{
${ }^{1}$ Figur hentet fra File:Ladder of inference.svg - Wikimedia Commons
} 
handlingsrom. Innebygde drivkrefter i enhver hierarkisk organisering belønner konformitet og servilitet på bekostning av kritisk tenkning, som er forutsetningen for rasjonalitet også i sin kognitivt begrensede form (Kahneman, 2003). Organisasjoner mangler derfor tilpasningsevne. Innarbeidede kognitive strukturer og prosedyrer overstyrer politisk mål (Allison \& Zelikow, 1999).

Militære har dessuten egeninteresse i et tilstrekkelig spenningsnivå til å bekrefte deres misjon og posisjon. Det gjelder også dem som i alle atommakter har sin posisjon og dermed egeninteresse investert $\mathrm{i}$ atomvåpen. Det kom klart fram i en debatt forfatteren fulgte i det britiske Underhuset om moderniseringen av britiske atomvåpen. De som ville avskaffe dem, ble møtt med det retoriske spørsmål om hva de ville si til de 35000 som da angivelig kom til å miste jobben. Da Biden som Obamas visepresident skulle forhandle med Kongressen om ratifisering av NYE START, avtalen med Russland om nedrustning av atomvåpen, måtte han gå med på å modernisere atomvåpenbasene $\mathrm{i}$ enkelte valgdistrikt, $\mathrm{i}$ tillegg til å godta at avtalen ikke stod i veien for et amerikansk rakettforsvar i Europa (McFaul, 2018). Også utviklingen av rakettforsvar lokker med lukrative forretningskontrakter. Dermed undergravde innenrikspolitiske kompromisser med særinteresser den skjøre enighet med Russland om atomvåpen.

Forfatteren har kommet til at denne egeninteressen blant begrensede interessegrupper er den sterkeste drivkraften i atomvåpenkappløpet. Det betyr at forskjellige atomvåpenstrategier ikke er den egentlige årsak til atomvåpen, men en rasjonalisering av smale sektorinteresser i de forskjellige stater. At rasjonaliseringen tjener begrensede interesser, skaper samtidig et handlingsrom for rasjonelle argumenter mot atomvåpenstrategiene.

Atomvåpenstrategier blir innfløkte tankekonstruksjoner som alle planlegger et utenkelig valg, nemlig atomkrig. Men når enkeltmennesker står overfor dette valget, under et ufattelig press med helt ekstremt stressnivå, har deres innsikt i atomstrategiene neppe særlig betydning. Deres valg reduseres til et grunnleggende eksistensielt spørsmål: Vil jeg utøse apokalypsen? Det rasjonelle valg er selvsagt under enhver omstendighet nei!

Vi kjenner til fire tilfeller der enkeltmennesker i vidt forskjellige, men alle svært kritiske situasjoner har svart nei til å utløse atomkrig. Den sovjetiske ubåten under Cuba-krisen, som i dypet ble rystet av amerikanske dypvannsbomber, avfyrte ikke sine torpedoer med atomladning fordi én av de tre som i henhold til sovjetiske prosedyrer måtte være enige stod imot (Plokhy, 2021; Savaranskaya, 2005). Dette fortettede drama i havdypet, under trengselen i trange trapper med lyset fra flakkende lommlykter (Plokhy, 2021), viser at det er mellommenneskelig dynamikk i små grupper som i akutte kriser avgjør krig og fred; ikke innfløkte strategier og doktriner. Det samme viser tautrekkingen om Israel skulle bruke mindre atomvåpen i en kritisk situasjon under krigen i 1973, da statsminister Golda Meir stod imot press fra forsvarsminister Moshe Dayan (Bundy, 1988; Shultz \& Goodby, 2015). Verden ble reddet fra undergangen i 1983 av en enkelt sovjetisk offiser, Stanislav Petrov. Han var på vakt i den sovjetiske kommandobunkeren da systemet feilaktig varslet om et 
atomangrep fra USA. Hans sunne fornuft overprøvde prosedyrene han var pliktig til å følge. I strid med sine instrukser unnlot han å melde videre om at systemet varslet et amerikansk atomangrep (Hoffman, 2010). ${ }^{2}$

En slik rasjonell vurdering i en krise er dessverre langt fra selvsagt. Omtrent samtidig med at Stanislav Petrov på vakt i den sovjetiske atomvåpenbunkeren egenhendig avverget atomkrig ved å unnlate å følge ordre, sparket sjefen for USAs strategiske atomvåpen, NORAD, en offiser som under en øvelse nølte med å «utslette» Sovjetunionen, noe NORAD-sjefen til overmål bekreftet offentlig (Carter et al., 1987). Det skjedde samtidig som nettopp frykten for at USA ville angripe Sovjetunionen med atomvåpen, var på nippet til å utløse et sovjetisk atomangrep, et forkjøpsangrep. Det var nettopp et slik sovjetisk atomvåpenangrep USAs atomstyrker skulle forebygge ved å true med å angripe. Med andre ord skapte sjefen for USAs såkalte strategiske atomvåpen uforvarende en risiko for atomkrig, en apokalypse som den sovjetiske offiser Stanislav Petrov egenhendig forhindret. At atomvåpenstrategiene er farlige, kan neppe illustreres tydeligere.

Det var ikke atomvåpenstrategienes avskrekking som reddet Norge fra undergangen i 1995, men Russlands president Jeltsin som stod imot press fra en general som ville bruke atomvåpen mot Norge for det han feilaktig oppfattet som et angrep; i virkeligheten en rakett fra Andøya som skulle skyte opp en værvarslingssatelitt (Pry, 1999).

Disse eksemplene på at enkeltindivider i en gruppedynamikk redder verden ved å unnlate å følge atomvåpenstrategiene til ytterste konsekvens, atomkrig, viser at selve strategiene er urealistiske i sitt logisk selvmotsigende premiss - at atomkrig må være mulig for å bli umulig. Om man tross selvmotsigelsen godtar dette premisset, som blant annet Norge fremdeles gjør, forutsetter det likevel en kontroll over krisers utvikling som ikke er realistisk. Atomstrategiene forutsetter et endimensjonalt, nærmest mekanisk årsaksforhold, mens stater i en krise i virkeligheten gjensidig reagerer på sine oppfatninger av hverandre i et svært komplekst, høyst utsabilt og eskalerende dynamisk samspill (Kahneman \& Renshon, 2007). Dette var innsikten president Kennedy kom til under Cuba-krisen i 1962 (Kennedy \& Schlesinger, 2011).

Det er selve forståelsen av strategi som er det mest grunnleggende uholdbare premiss i atomstrategiene. Atomstrategier operer med urealistiske, forenklede forestillinger om årsak og virkning som ingen egentlig tror på. Derfor er atomstrategier farlige nettopp fordi de ikke er overbevisende. I stedet for å avskrekke, kan de utløse panikk for en overhengende fare for angrep med katastrofale følger. Der frykten for atomangrep tar overhånd, kan det virke som bare forkjøpsangrep er i stand til å redusere ødeleggelsene mot eget samfunn og befolkning. Atomstrategier blir farlige ved sin innebygde selvmotsigelse, at atomkrig, under enhver omstendighet et umulig valg, likevel må være mulig for å bli umulig. Det viser atomstrategienes utvikling, som desperate forøk på å løse denne selvmotsigelsen.

\footnotetext{
${ }^{2}$ https://www.opendemocracy.net/en/when-personal-courage-saved-world/
} 


\section{Hvordan har atomstrategier utviklet seg?}

Atomstrategienes utvikling kan bare forstås som til dels desperate forsøk på å løse de egentlig uløselige dilemmaer atomvåpen stiller stater overfor. President Eisenhower mente på 1950-tallet at hans strategi for massivt atomangrep mot Sovjetunionen, for avskrekke Sovjetunionen mot å bruke sin konvensjonelle militære overlegenhet til angrep, var tilstrekkelig til å hindre både aggresjon og krig. Kritikken mot denne strategien var at den ikke tok høyde for krisehåndtering, og at også en atomkrig om mulig måtte kunne begrenses og avsluttes før total ødeleggelse.

Henry Kissinger mente tidlig at en strategi med fleksibel respons var bedre enn umiddelbar full atomkrig både for avskrekking og krisehåndtering, mens Robert McNamara som forsvarsminister forsøkte det samme som Kissinger ved å skille mellom angrep på militære mål (counterforce) og byer og kritisk sivil infrastruktur (countervalue). Disse forsøkene strandet i en erkjennelse av at det ikke var realistisk å begrense en atomkrig. USA gikk derfor tilbake til president Eisenhowers doktrine, denne ganger under betegnelsen "MAD - Mutually Assured Destruction» (Bundy, 1988). Forestillingen bak var at det ingen kunne overleve, ville ingen heller forsøke.

Problemet med MAD ble at når konsekvensene var umulige, var de heller ikke troverdige som trussel for å avskrekke. Dette problemet forsøkte nye strategier å løse på to måter. For det første skulle store mengder atomvåpen med amerikanske styrker i forreste linje i særlig Tyskland føre til massiv bruk i en tidlig fase av en krig ("use them or lose them»), og dermed begrense USAs presidents mulighet til å unndra seg sin plikt til å starte atomkrig for å gjengjelde angrep på Europa (Hellestveit \& Egeland, 2020). For det andre skulle visse typer atomvåpen med lav sprengkraft og strålefare styrke den konvensjonelle slagkraft. Det gjaldt alt fra miner, granater, bomber og kortdistanseraketter, men særlig kanskje planene om en nøytronbombe, som med kort strålevirkning og uten sprengkraft («a cleaner kill») kunne bli det ideelle angrepsvåpen.

Disse strategiene ble etter hvert også forlatt som farlige, både ved at de senket terskelen for krig og samtidig var urealistiske i sin antagelse om at ikke enhver bruk av atomvåpen ville eskalere. Det er for eksempel nå antatt at selv torpedoene med liten atomladning som lå skuddklare i de sovjetiske ubåtene under Cuba-krisen, kunne utløst full atomkrig (McNamara, 2009). Planene for nøytronbombe ble forlatt og Tyskland ryddet for de mindre atomvåpen som skulle tjene som «snubletråder». Nå, under de pågående konfrontasjonene med Russland, kommer nye planer om å styrke også konvensjonell slagkraft med mindre atomvåpen ledsaget av en ide om at en slik krig kan «vinnes» (Hellestveit \& Egeland, 2020), sannsynligvis også på russisk side (Perry, 2015). ${ }^{3}$

\footnotetext{
${ }^{3}$ Forfatterens samtaler i Minsk
} 
Det betyr at nye, urealistiske ideer om atomvåpenstrategier gror fram omtrent som farlige virus når politiske konfrontasjoner senker vårt analytiske immunforsvar. En effektiv motgift burde være å se hvordan sentrale beslutningstakere i ettertid vurderer sin forståelse av de atomstrategier de var med på. To av dem, Robert McNamara og Henry Kissinger, har tatt avstand fra atomvåpen med ny innsikt $i$ faktiske forhold de tidligere med begrenset kunnskap måtte forholde seg til i beslutningsprosessene.

McNamara oppdaget at Cuba-krisen i 1962 hadde vært mye farligere enn han trodde. Han møtte russiske og kubanske aktører fra den gang på Cuba i 2003. Det var særlig fire forhold som skremte ham. For det første oppdaget han først da at sovjetiske ubåter som ledsaget skipene med rakettdeler og atomladninger til Cuba, også førte torpedoer med atomladninger. For det andre oppdaget han at Kreml av praktiske årsaker hadde delegert myndighet til å bruke atomvåpen til lokale militære ledere, om bord i ubåtene og på Cuba. For det tredje fortalte Castro ham direkte at han hadde bedt Kreml om at de måtte svare på et amerikansk angrep med atomvåpen, selv om det betød Cubas utslettelse. Poenget for Castro var at det også ville føre til USAs utslettelse. Et amerikansk angrep hadde McNamara under Cuba-krisen i 1962 bare avverget på hengende håret. For det fjerde hadde de sovjetiske ubåter fortsatt sine tokt $\mathrm{i}$ dagevis etter at Sovjetunionen og USA hadde blitt enige om å bilegge striden. På sin ensomme ferd med skuddklare atomvåpen hadde ikke de sovjetiske ubåtmannskapene fått høre at den farlige krisen var over. McNamara kom derfor til at atomvåpen under alle omstendigheter i seg selv var farlige (McNamara, 2009). Det samme har Henry Kissinger kommet til sammen med en rekke andre sentrale politikere i USA (Shultz et al., 2007-2011), Tyskland ${ }^{4}$ og nå Norge (Bondevik et al., 2020). Alle har inngående kjennskap til atomvåpen og atomvåpenprosedyrer, alle vil avskaffe atomvåpen. Sagt med fjellvettreglene: Lytt til kjentfolk! Fjellvettreglene gjelder spesielt i uvær. I sikkerhetspolitikk er kalde kriger farlige.

\section{De tre kalde kriger}

Spørsmål om atomvåpenavskrekkingens risiko og troverdighet er blitt aktuelle fordi Vestens forhold til Russland har utviklet seg fra samarbeid og politisk dialog til en ny konfrontasjon med klare likhetstrekk til den kalde krigen. Vi er nå i virkeligheten i en ny kald krig. Den kalde krigen hadde to klare tidligere faser. Den tredje kalde krigen, som vi nå befinner oss i, har urovekkende likhetstrekk med den første halvdel av den andre kalde krigen.

Den første kalde krigen varte fra det kommunistiske kuppet i Tsjekkoslovakia i 1948 og fram til Cuba-krisen i 1962. På kanten av stupet til atomkrig forstod både

\footnotetext{
${ }^{4}$ https://www.wz.de/politik/schmidt-weizsaecker-genscher-und-bahr-fordern-atomare-abruestung aid-31211321
} 
USA og Sovjetunionen at det var i felles interesse å redusere risikoen for atomkrig gjennom rustningskontroll, særlig Ikkespredningsavtalen for atomvåpen, men også avtalen om nødtelefon mellom Washington og Kreml, og, som ledd i den første avtalen om rustningskontroll for atomvåpen, SALT, også forbud mot å undergrave terrorbalansens stabilitet med rakettforsvar (ABM) (Bundy, 1988; Preston, 2010). Konferansen for sikkerhet og samarbeid i Europa i 1975 slo fast noen prinsipper for sameksistens basert på eksisterende politiske realiteter (Bahr, 1996; Brandt, 2013). Men den felles sikkerhet skulle vare i bare fire år. Sovjetunionens invasjon av Afghanistan på tampen av 1979 og NATOs atomopprustning i Europa som svar på de nye sovjetiske mellomdistanserakettene innledet den andre kalde krigen, som endelig tok slutt med Berlinmurens fall og omveltningene i Øst-Europa høsten 1989.

Den tredje kalde krigen, som vi nå opplever, utviklet seg gradvis fra Vladimir Putins tale i 2007 på sikkerhetskonferansen i München (Shanker \& Landler, 2007; Teltschik, 2019). Den ble akutt i 2014 etter Russlands erobring av Krim og påfølgende aksjoner i det østlige Ukraina, med store konsekvenser for krisehåndtering i Midtøsten (Fjærtoft, 2019b). Samtidig skaper Russlands opprustning bekymring for europeisk sikkerhet. For en tenkelig slagmark har Russland Iskander, nye mobile raketter, som også kan føre mindre atomladninger.

Dette mønsteret av konflikteskalering har klare fellestrekk med utviklingen i den andre kalde krigen i første halvdel av 1980-tallet. Risiko og muligheter i forhold til Russland i dag kan vi derfor analysere ved å sammenlikne med utviklingstrekk den gang.

\section{Forskningsprosjektet og dets relevans}

Denne artikkelen presenterer forfatterens forskning om sikkerhetspolitisk handlingsrom i første halvdel av 1980-tallet, den andre kalde krigen. Den viktigste frontlinjen gikk mellom de daværende to tyske stater, som hadde en framskutt posisjon i hver sin militærblokk.

Interne, lukkede prosesser i sensitive sikkerhetspolitiske spørsmål i det daværende $\mathrm{DDR}$ er i dag åpne for innsyn. Gjennom samtaler med sentrale tyske og andre aktører i begge de tyske stater under denne tilspissede perioden av den andre kalde krigen får vi en realistisk analyse av strukturer og dynamikk i konfrontasjoner. ${ }^{5}$ Sammenliknbart er strukturer og dynamikk som styrer dagens konfrontasjoner.

Skarpe, uforsonlige ideologiske og politiske motsetninger innskrenker handlingsrommet for politisk dialog, den gang som nå. Som et analytisk verktøy for en sikkerhetspolitisk dialog med Russland i dag trenger vi derfor en bedre innsikt $i$ handlingsrommet for politisk dialog om sikkerhetspolitiske problemer mellom de to tyske stater i første halvdel av 1980-tallet. Forfatteren har møtt kildene på forskjellige

\footnotetext{
${ }^{5}$ Alle samtaler er fortrolige og derfor underlagt standard prosedyre for kildebeskyttelse, Chatham House Rule.
} 
seminarer i Tyskland og en i Israel. Viktige arenaer har vært Egon-Bahr-symposier i Willy-Brandt-kretsen der forskere, diplomater og politikere har drøftet utviklingen i den tyske østpolitikken fram til konferansen for sikkerhet og samarbeid i Europa i 1975. Østpolitikken var en kursendring i vesttysk politikk overfor Sovjetunionen, og deretter Polen, Tsjekkoslovakia og DDR. Formålet med å drøfte den tyske østpolitikken har vært å anvende en tilsvarende tilnærming i forholdet til Russland i dag.

På tross av det gjensidig fiendtlige politiske klima under den andre kalde krigen i første halvdel av 1980-tallet, var det en gryende tysk-tysk politisk dialog om felles sikkerhet på tvers av blokkgrensene. Fra østtysk side foregikk dialogen særlig i regi av representanter for to forskningsinstitusjoner for utenrikspolitikk og militærstrategi, på vesttysk side var dialogen forankret i fredsforskningsinstituttet i Hamburg under Willy Brandts nære rådgiver i østpolitikken, Egon Bahr (Bahr, 1996, 2012, 2013; Brandt, 2013; Merseburger, 2013).

Mine samtaler med sentrale aktører fra den gang i begge de tyske stater, på hver sin side av jernteppet, gjør det nødvendig å korrigere det hevdvunne bildet av sovjetisk manipulering bak de østtyske forskeres dialog med vesttyske motparter. Selv om det sikkert var krefter i DDRs maktapparat som så den gryende dialog med de vesttyske sosialdemokrater som en maktpolitisk mulighet til å undergrave NATO, vet vi nå at det var en voksende bekymring for sovjetiske militærdoktriner blant en kjerne av sikkerhetspolitiske eksperter i det daværende DDR som etter hvert fant en kanal til vesttyske motparter.

Bak de sovjetiske militærdoktriner stod sterke fiendebilder av NATO, som ble tillagt aggressive hensikter. De sovjetiske operasjonsplaner så DDR som frontlinje i en krig med NATO. Det som gjorde den militære tankegangen farlig, var tre grunnleggende premisser: For det første ulmet frykten for et NATO-angrep i den sovjetiske forestillingsverden. I Kreml svingte angrepsfrykten mellom mulig risiko og overhengende fare. For det andre skulle deres forsvarskrig i en massiv framrykking i et overraskelsesangrep raskt knuse fiendtlige styrker på fiendens eget territorium. For det tredje førte denne tankegangen til en urealistisk forestilling om «seier», helst rask.

De tre grunnleggende premissene $\mathrm{i}$ den sovjetiske militære tankegang kunne $\mathrm{i}$ en krise skape en dynamikk for forkjøpsangrep. Ved fare for et forestående fiendtlig angrep gjaldt det å slå til først. Derfor hadde de store sovjetiske styrker i DDR en høy beredskap for et massivt overraskelsesangrep mot Vest-Tyskland. Også sovjetiske atomraketter var stasjonert i DDR, klare til bruk. ${ }^{6}$ De skulle komme et NATOangrep med de nye atomrakettene i Vest-Tyskland i forkjøpet. «Dere kan stille opp så mange atomraketter dere vil, vi er forberedt. Den som først trykker på knappen har en fordel.» Slik uttrykte den sovjetiske nedrustningsforhandler (og senere russisk ambassadør i Oslo), Yuli Kvitsinsky, seg overfor Egon Bahr (Bahr, 2013). Misforståelser om motpartens hensikter var derfor tilstrekkelig til å utløse massiv krig i Europa.

\footnotetext{
${ }^{6}$ Kilde i DDRs hær
} 
Den sovjetiske forestillingsverden, der NATO var en alvorlig trussel, ble delt av de politiske og militære eliter i DDR. Men enkeltpersoner hadde varierende grad av evne til fleksibel og pragmatisk tenking; universelle forskjeller i enhver hierarkisk organisering. Individuelle forskjeller i kognitiv fleksibilitet kan få stor betydning for politiske løsninger i konfrontasjoner (Aronoff, 2014). Det var en gruppe med større kognitiv fleksibilitet - og mot - enn det konforme flertall i den østtyske kommuniststaten som klarte å gjennomføre den sikkerhetspolitiske dialog med vesttyske motparter. De maktet å overvinne mistenksomhet og motstand i to faser, først internt i det østtyske maktapparatet, så overfor vesttyske aktører, som - ikke uten grunn mistenkte at DDR-representanters legitime oppdrag i vest også tjente propaganda og spionasje (Grossmann, 2007; Wolf, 2003).

I den sovjetiske militærstrategi var det særlig forestillingen om seier som stadig flere sikkerhetspolitiske eksperter i DDR begynte å finne meningsløs etter de enorme ødeleggelser i begge tyske stater selv en krig uten atomvåpen ville medføre. Av denne erkjennelse fulgte en viktig innsikt; at sikkerhet ikke lenger var realistisk mot, bare med fienden. Med andre ord ble de tilhengere av forestillingen om felles sikkerhet.

Det var med denne erkjennelsen de østtyske sikkerhetspolitiske ekspertene fikk kontakt med Willy Brandts nære sikkerhetspolitiske rådgiver, Egon Bahr, da han ledet fredsforskningsinstituttet i Hamburg. Felles sikkerhet var hans visjon, som han gjorde til det sentrale budskap i Palme-kommisjonen i 1982 (Bahr, 2012). Egon Bahr utviklet tre hovedprinsipper for felles sikkerhet (Fjærtoft, 2019a, 2019b): ${ }^{7}$

1. Sikkerhet må være delt for å være sikker

2. Forslag er bare realistiske dersom alle parter oppfatter det bedrer deres sikkerhet

3. All kommunikasjon begrenser seg til praktisk forbedring av sikkerhet, ingen forsøk på å overtale motparten i politiske eller ideologiske spørsmål

Betydningen av å følge disse tre prinsipper i en prosess for felles sikkerhet ble uforvarende vist av Egon Bahr selv da han brøt dem. En kilde blant de østtyske sikkerhetspolitiske ekspertene som møtte Bahr, forteller i ettertid at han plutselig slo fast at de på tross av dialogen om felles sikkerhet, forble fiender. Sannsynligvis ønsket Egon Bahr med en slik uttalelse å styrke sitt prinsipp 3 ovenfor, men virkningen ble en annen. De østtyske samtalepartnerne, som selv hadde satt seg $\mathrm{i}$ en sårbar situasjon i sitt eget system ved å ta kontakt med ham, fant uttalelsen så bekymringsfull at de for sikkerhets skyld rapporterte den til HVA, Hauptverwaltung Aufklärung, DDRs utenlandsspionasje. Det var sikkert fornuftig for å skaffe seg ryggdekning internt i DDR, men rapporteringen av uttalelsen kunne fått som følge at hele dialogen ble stoppet siden det kunne tolkes som en bekreftelse på fiendebildet av NATO.

\footnotetext{
${ }^{7}$ Samtaler med Egon Bahrs tidligere nære medarbeidere
} 
Ryggdekning internt $\mathrm{i}$ egen leir er en forutsetning for gjennomslag for all nytenkning som leder til politiske initiativ. Uten intern ryggdekning kan ingen omstilling lykkes. Det gjaldt like mye i begge de to tyske stater. Også Willy Brandt og Egon Bahr måtte i sin østpolitikk sikre seg ryggdekning, først innenrikspolitisk og deretter internasjonalt. ${ }^{8}$ Svekkelse av Vest-Tysklands allianser var hverken hensikt eller virkning av deres sikkerhetspolitiske nytenkning. Bare ryggdekning i vestlig forankring, med USA gjennom NATO, og Frankrike og Storbritannia gjennom EU, gjorde det mulig å endre forholdet til Sovjetunionen (Bahr, 1996; Merseburger, 2013). Det samme behov for intern ryggdekning i sikkerhetspolitisk nytenkning gjelder i dag både i NATOs medlemsland og i Russland. Det betyr at bare ved å anvende Egon Bahrs prinsipper for felles sikkerhet, at alle forslag må være i felles interesse uten å reise utenforliggende spørsmål, har en ny politisk dialog med Russland en realistisk prognose for å føre til bærekraftige sikkerhetspolitiske endringer.

Et viktig funn er at det på tross av behovet for intern ryggdekning, også innenfor et totalitært regime som det østtyske var rom for ulike oppfatninger om sentrale sikkerhetspolitiske spørsmål. Mangelfull vestlig innsikt i de interne prosesser i DDR og Sovjetunionen førte til at et vestlig handlingsrom for felles sikkerhet ikke ble erkjent og utnyttet. Det gjaldt begge de to stridsspørsmål som utløste den andre kalde krigen, Sovjetunionens invasjon av Afghanistan (Kalinovsky, 2009) og atomvåpenopprustningen (Bahr, 1996, 2012; Kubiczek et al., 2014). Derimot fikk vestlige politiske veivalg med en rasjonell begrunnelse som utilsiktet virkning at faren for krig, også atomkrig, økte, i kritiske faser til et svært farlig nivå (Fischer, 1997; Grossmann, 2007; Pry, 1999; Schild, 2013). Disse historiske erfaringer kan tjene som kognitive verktøy for å analysere aktuelle norske sikkerhetspolitiske spørsmål.

\section{De to grunnleggende spørsmål i norsk sikkerhetspolitikk}

Den norske regjerings vurdering av om Norge kan slutte seg til FNs totalforbud mot atomvåpen, gjelder to spørsmål:

1) Kan FNs totalforbud mot atomvåpen hindre atomkrig?

2) Hvordan virker avskrekking av politisk press og angrep?

Disse spørsmålene mangler sikre svar. Årsaksforhold, og dermed både tilsiktede og utilsiktede virkninger av politiske veivalg, blir uunngåelig hypotetiske.

\section{Hindre atomkrig}

Det er ingen uenighet om at atomvåpen er en eksistensiell trussel, og at atomvåpen derfor aldri må brukes. Et totalforbud mot atomvåpen virker innlysende fornuftig, og går nøkternt vurdert neppe lenger enn eksisterende forpliktelser.

\footnotetext{
${ }^{8}$ Nær kilde til Willy Brandt: «Sie gingen sehr tastend vor»
} 
Ikkespredningsavtalen, som Norge sluttet seg til allerede i 1970, forplikter til atomnedrustning med sikte på avskaffelse. Til sammenlikning har kjemiske våpen vært forbudt lenge, et forbud som på tross av enkelte alvorlige brudd, sist i Syria, har forebygd den massive bruk vi så under første verdenskrig (Price, 2019). Det er derfor en milepæl i retning av en mer rasjonell internasjonal orden når FN-traktaten som forbyr atomvåpen, formelt trådte i kraft 22. januar i år. To tidligere norske statsministere, sammen med tidligere utenriks- og forsvarsministere, har gått imot et norsk forsvar knyttet til andre NATO-staters atomvåpen (Bondevik et al., 2020).

Det virker derfor lite fornuftig at den norske regjering sammen med våre alliansepartnere i NATO unnlater å støtte et totalforbud mot atomvåpen så lenge andre stater har disse våpen. Under de rådende politiske forhold er initiativ for atomnedrustning ikke å forvente fra land som er i ferd med å modernisere og til dels øke sine atomvåpen. Det gjelder ikke bare USA og Russland, men også Norges nære militære alliert, Storbritannia (Reuters, 2021). Derfor gjør den norske regjering FNs totalforbud mot atomvåpen, som er innlysende fornuftig, til en urealistisk utopi. En mer realistisk norsk politikk for atomnedrustning enn å vente på at alle atomvåpen forsvinner, ville være å ta et politisk initiativ for atomnedrustning overfor likesinnede europeiske land. Men et norsk dilemma hindrer den norske regjering så langt å ta et slikt initiativ.

Sikre avskrekking

Regjeringens betenkeligheter med et atomvåpenforbud gjelder ikke atomvåpen, men forholdet til USA og Russland. Det norske dilemma er hvordan Norge kan unngå en uakseptabel risiko for at atomvåpen virkelig kan bli brukt, uten samtidig å øke risiko for russisk press og i verste fall angrep. For et lite naboland utgjør russisk opprustning et sikkerhetsproblem uavhengig av om opprustningen er defensiv, noe den åpenbart er (Perry, 2015).

Et rasjonelt argument mot ensidig atomnedrustning er at selv forestillinger om ubalanse kan endre maktforhold, det den klassiske kinesiske strateg Sun Tzu beskrev som militærmaktens viktigste formål, å «vinne uten å kjempe» (Tzu et al., 2006). I verste fall kan politisk press ende $\mathrm{i}$ begrensede militære aksjoner i lavintensivkonflikter. I den aktuelle kampen mot atomvåpen lar det seg derfor ikke overse at Russlands annektering av Krim og aksjoner i Ukrainas grenseområder er en kvalitativ ny dimensjon i trusselbildet. Det gjelder uavhengig av om russiske motiver er defensive, og på tross av at Norges forhold til Russland ikke kan sammenliknes med Ukrainas. (Både Russlands og Europas sikkerhet ville vært betydelig bedre om Ukrainas forhold til Russland var som Norges, der mennesker i grenseområdene blir en pressgruppe for forståelse og samarbeid over grensene.)

Også med det gode naboforholdet er en snikende sikkerhetspolitisk risiko for Norge at en selvstendig demokratisk stat uten troverdig forsvar og bærekraftige allianser kan utvikle seg i retning av et lydrike for en totalitær stat. En slik utvikling kan komme gradvis ved tilpasninger over tid. FNs atomvåpenforbud stiller derfor 
enhver norsk regjering overfor et reelt dilemma som ikke kan overses i den rasjonelle kampen mot atomvåpen. Sikkerhetspolitikk må finne en farbar vei gjennom målkonflikter.

Fred eller krig, frihet eller dominans, avgjøres ikke ved objektive, målbare variabler, men av partenes subjektive forestillinger om trusler, mål, midler og risiko. Formålet med en sikkerhetspolitikk er å påvirke mulige motparters forestillinger om et realistisk handlingsrom og blokkere mulige fienders ideer om offensive opsjoner (Freedman, 2015a, 2015b; Gaddis, 2018). Avskrekking må veies mot krigsfare, siden krig er mulig som følge av svikt i risikovurdering (Allison \& Zelikow, 1999; Clark, 2012; Kennedy \& Schlesinger, 2011).

Den sikkerhetspolitiske dragkamp foregår i partenes hoder, på en imaginær slagmark. Det springende punkt er om atomvåpen styrker avskrekking når konsekvensene av atomvåpenkrig undergraver atomvåpenstrategiers troverdighet. Blant tidligere politikere med egen erfaring $\mathrm{i}$ atomstrategiers utforming, er det delte meninger. En veteran som $\mathrm{McGeorge}$ Bundy, en nær rådgiver for presidentene Kennedy og Johnson på 1960-tallet, mente selv en liten risiko for at atomvåpen kan brukes, er tilstrekkelig avskrekking (Bundy, 1988). En annen veteran er William J. Perry, som brukte store deler av sitt yrkesaktive liv på å utvikle atomvåpen fram til han ble president Clintons forsvarsminister. Han er, som Bundy, opptatt av at ideen om atomvåpenbalanse øker risikoen for atomkrig uten å styrke avskrekkingen. Som Bundy mener han at selv en liten risiko er tilstrekkelig avskrekking, og går derfor inn for ensidige amerikanske kutt (Perry, 2015).

Et annet spørsmål er om Bundy og Perry med sine erfaringer med USAs atomvåpenstrategier mener USAs «atomparaply» sikrer at USA vil bruke egne atomvåpen som svar på angrep på andre land. I så fall risikerer USA selv å bli rammet av massive motangrep med fiendtlige atomvåpen. Det avgjørende spørsmål er hvor stor usikkerhet om hvorvidt USAs faktisk vil følge "atomparaplyen», er nødvendig for at den skal hindre press, blokkere offensive opsjoner og avskrekke angrep? En annen veteran fra USAs atomstrategier, Henry Kissinger, avviser kategorisk at USAs «atomparaply» er troverdig på grunn av katastrofale konsekvenser for USA om deres atomvåpen virkelig skulle komme til bruk (Pelopidas, 2015). Dette virker umiddelbart sannsynlig, men er likevel ikke helt sikkert.

Alle misforstår avskrekkingens vesen, både de som mener en liten restrisiko for atomvåpen er tilstrekkelig avskrekking, og de som mener at i hvert fall «atomparaplyen» ikke er realistisk. Enhver forsvarsstrategi er imaginær, siden de scenarioer den skal blokkere, bare eksisterer som tankekonstruksjoner, og konsekvenser følgelig er imaginære. Avgjørende er hvordan partene forestiller seg årsaksforholdene. De forestillingene skapes gjennom hvordan de kommuniseres. Slagmarken er i våre hoder.

En avskrekking med atomvåpen virker derfor bare om andre stater i sin tenkning innretter seg etter det. At det ikke nødvendigvis er tilfelle, blir Israel kanskje det mest innlysende eksempel på. Israel er i en svært sårbar sikkerhetspolitisk situasjon, omgitt av stater og grupper som vil avskaffe staten med uviss skjebne for de jøder 
som bor der. Israelske atomvåpen har ikke hindret hverken trusler eller angrep, $\mathrm{i}$ hvert fall ikke i noe kjent tilfelle (Pelopidas, 2015). At Israels mange fiender rett og slett ignorerer trusselen fra israelske atomvåpen, kan vi tolke som bevis på at atomvåpen ikke er nødvendig for avskrekking, hverken i Israel elle andre land. Derimot utsetter Israel og andre små atommakter seg i en krise for massive forkjøpsangrep fra overlegne atomstyrker (Pry, 1999). Under forfatterens samtaler i Teheran anførte iranske representanter nettopp denne faren som bevis for at Iran ikke vil ha atomvåpen, et argument som sikkert også anføres internt overfor dem som vil ha iranske atomvåpen (Fjærtoft, 2019b).

Samtidig som Israel viser at atomavskrekking ikke virker om den ikke oppfattes som avskrekking av potensielle angripere, er statens konvensjonelle militærmakt et bevis på at et effektivt forsvar er mulig uten atomvåpen. Uavhengig av hva vi måtte mene om Israels politikk for øvrig, kan derfor landets forsvar tjene som modell for Norge.

Satt på spissen er det sentrale spørsmålet i vurderingen av om Norge kan slutte seg til FNs totalforbud mot atomvåpen: Tror sentrale aktører virkelig at USA vil innlede atomkrig for Svalbard? Det er så utenkelig at det neppe gjenstår en tilstrekkelig restrisiko til at det $\mathrm{i}$ en krise ville blokkere press eller offensive opsjoner. Med andre ord spiller "atomparaplyen» i realiteten liten eller ingen rolle for Norges sikkerhet. Men Norge trenger, som alle land, en sikkerhetsstrategi som forebygger at farlige misforståelser utsetter oss for forkjøpsslag med atomvåpen.

\section{Farlige misforståelser}

Artikkelen redegjorde innledningsvis for hvordan våre kognitive prosesser skaper ulike mentale modeller av virkeligheten. En sikkerhetspolitikk må derfor forholde seg til hvordan motstridende mentale modeller skaper konflikter. Når de mentale modeller er uforenlige og begge parter oppfatter seg som truet av den andre, har begge parter vanskelig for å forstå hvordan egne utsagn og handlinger utløser utilsiktede motreaksjoner. De kan også overvurdere sin kontroll over utviklingen (Kahneman, 2003; Kahneman \& Renshon, 2007). Derfor er enhver forsvarsstrategi med atomvåpen farlig også i dag. Under den pågående tredje kalde krigen utvikler det politiske klima seg nå i en retning der atomstrategiene kan bli farlige, som under den andre kalde krigen. Som et eksempel kan forfatteren vise til sine samtaler på et av de norske militærmaktseminarene. Der ble i full offentlighet den militære trussel fra Russland begrunnet, men ikke nyansert eller problematisert. I pausen spurte forfatteren representanter for Storbritannia og Frankrike om de virkelig kunne tenke seg situasjoner der de ville avfyre sine lands atomvåpen. Uten å nøle svarte de ja, siden det var nødvendig for å avskrekke Russland. Problemet som de og de tilstedeværende norske offiserer og diplomater overså, var selvsagt at Russland tenker nøyaktig på samme måten om sine atomvåpen og selv føler seg truet av overlegne fiender (Perry, 2015), slik blant andre den norske E-tjenesten dokumenterer i sin 
åpne rapport (Etterretningstjenesten, 2021). Uenighet om trusselvurderinger kan bli farlig om unyanserte fiendebilder får overtaket.

En svært farlig uenighet under den andre kalde krigen var topphemmelig og ble først avslørt etter at den var slutt. Hadde de motstridende mentale modeller uenigheten dreide seg om vært kjent, ville vestlige sikkerhetspolitiske veivalg kunnet unngå utilsiktede virkninger som viste seg å bli farlige. Uten at sentrale beslutningstakere $\mathrm{i}$ Vesten var klar over det, møttes lederne for Sovjetunionens og DDRs spionasje sommeren i 1982 i hovedkvarteret for KGBs spionasje utenfor Moskva. Vi kjenner nå til møtets bakgrunn og forløp.

Konfrontasjonene som utløste den andre kalde krigen i første halvdel av 1980-tallet førte til en paranoia i Kreml for at USA skulle angripe Sovjetunionen med atomvåpen, det fryktede «førsteslag». Et «førsteslag» ville bety at mulighet for gjengjeldelse, «annet slag», hadde sviktet i å hindre atomangrep. Dermed begynte den lukkede krets av sovjetiske makthavere $\mathrm{i}$ Kreml å forberede seg på å forebygge ødeleggelsene fra USAs atomangrep ved å komme dem i forkjøpet, «forkjøpsslag». I deres hoder slo farlige tanker rot: Kunne ikke Sovjetunionen lenger hindre tredje verdenskrig, måtte de så langt som mulig begrense ødeleggelsene på eget territorium. ${ }^{9}$

For å vite når et forkjøpsslag ble nødvendig, bestemte Kreml at KGB skulle gjennomføre en omfattende systematisk overvåking av en liste med indikatorer i vestlige land på at et vestlig atomangrep var forestående, den såkalte Operasjon Ryan. Problemet med disse indikatorene var at de var urealistiske og derfor lett kunne føre til feilslutninger: Økte blodbanker sine blodlagre, lyste det sent i regjeringskontorer, var det aktivitet som tydet på forestående evakuering, og liknende (Fischer, 1997). KGB gav den fremste av etterretningstjenestene blant Sovjetunionens vasallstater, DDRs HVA - Hauptverwaltung Aufklärung, i oppdrag å støtte Operasjon Ryan (Fischer, 1997; Grossmann, 2007; Hoffman, 2010; Wolf, 2003).

Den østtyske spionsjefen, Werner Grossmann, visste at NATO ikke forberedte atomvåpenangrep på Sovjetunionen da han kom til møtet med KGB sommeren 1982. DDRs spioner hadde i praksis full innsikt i NATOs organer, særlig gjennom sin mest sentrale kilde, Rainer Rupp, kodenavn "Topas», en høyt betrodd medarbeider i NATOs sekretariat i Brussel. DDRs spionasjesjef trodde derfor på møtet i Moskva at han kunne berolige sin kollega og i praksis overordnede, sjefen for KGBs spionasje, Vladimir Alexandrovich Kryuchkov, når han fortalte at DDRs spion hos NATO med sikkerhet visste at ingen planla et atomangrep. Men til Grossmanns store overraskelse nektet Kryuchkov å tro på hans forsikringer. I stedet fikk den øst-tyske spionsjefen streng beskjed om å vise større årvåkenhet og fortsette å overvåke USAs og NATOs forberedelsene til atomvåpenangrep mot Sovjetunionen (Grossmann, 2007).

\footnotetext{
${ }^{9}$ Samtaler med en sentral rådgiver for forbundskansler Helmuth Kohl og en for president Reagan
} 
At Kreml i strid med de faktiske forhold fastholdt sin tro på et forestående atomvåpenangrep, var svært farlig siden de kunne angripe med atomvåpen $\mathrm{i}$ den feilaktige antagelse at de måtte komme et vestlig angrep i forkjøpet. Det er derfor svært viktig for norsk og vestlig militærstrategi også i dag å forstå hvordan noen kan tviholde på en dysfunksjonell virkelighetsforståelse som kan få svært farlige følger. Hvordan kan vi forklare det som skjedde på det topphemmelige møtet sommeren 1982 mellom den østtyske og sovjetiske spionsjef; at den ene fortalte sannheten, men den andre nektet å tro det?

Det bekymringsfulle ved situasjonen er at den ikke er enestående. Innledningsvis har artikkelen redegjort for kognitive teorier som viser at vi ikke hadde med anormale reaksjonsmønstre å gjøre, tvert imot. Slutningsstigen viser hvordan vi i våre mentale modeller blir fanget av våre antagelser. Det at KGB-sjefen handlet normalt, betyr at det samme kan skje igjen - og sannsynligvis både har skjedd og skjer. Derfor er den eneste reelle risiko for atomkrig, misforståelser om andre atommakters motiver i politiske kriser. Bare slik kan atomavskrekkingen svikte. Gjensidige misforståelser om skjulte motiver kan under kriser altfor lett bikke over fra rasjonell frykt til forestillinger om å måtte komme et angrep i forkjøpet. Flere og bedre atomvåpen på den ene eller begge sider løser ikke dette problemet, men forverrer det.

For sikkerhetspolitikk og militærstrategier blir vår bevissthet et farlig sted om vi ikke kan veien. Bare bedre beslutningsprosesser kan finne mer farbare veier enn i dag.

\section{Bedre sikkerhetspolitikk gjennom bedre beslutningsprosesser}

Våre analyser av framtidige problemer og løsninger er uunngåelig begrenset av våre historiske erfaringer. Kremls frykt under den andre kalde krigen for et vestlig atomangrep hadde sin rot i det tyske angrepet i 1941(Fischer, 1997), mens norsk sikkerhetspolitikk fremdeles styres av erfaringene med det tyske angrep i 1940. Vi har sett at Henry Kissinger mente historiske analogier er erfaringer som er relevante for andre problemer, the significance of a range of experience, men han minner om at svarene vi får ikke kan blir bedre enn spørsmålene vi stiller (Kissinger, 1973). Det er med andre ord ikke innlysende hvilke spørsmål og svar som er de riktige. Derfor er en bedre norsk sikkerhetspolitikk bare mulig gjennom en mer profesjonell norsk beslutningsprosess. Bedre analyser gir bedre beslutninger. Alle forstår noe viktig, ingen forstår alt. Systematisk uenighet skaper synergier og er derfor en nødvendig metode for å utvikle bedre politikk. Det er det viktige historiske eksempler på.

Under Cuba-krisen i 1962 gav president Kennedy sin bror Robert i oppdrag å sørge for at det alltid var uenighet i den innerste krets av rådgivere, og at de på tross av ulik hierarkisk posisjon drøftet på like fot (Kennedy \& Schlesinger, 2011). Dette var en beslutningsprosess med grunnleggende fellestrekk med den britiske system for beslutninger i komiteer under andre verdenskrig (Allison \& Zelikow, 1999). 
Under sin gjennomgang av USAs politikk i Afghanistan gav president Obama sin visepresident Biden samme oppgave; å sørge for uenighet (Woodward, 2010). I Stortingets utvalg for evaluering av Norges Libya-krig anføres det samme - at analyse blir bedre gjennom systematisk uenighet (Forsvarsdepartementet $\&$ Utenriksdepartementet, 2018).

Viktigste årsak til svikt i norske beslutningsprosesser er manglende systematisk uenighet for å få fram bedre analyser giennom synergier. Til sammenlikning viste møtet sommeren 1982 mellom den østtyske og sovjetiske spionssjef hvor farlig det er å avvise og undertrykke divergerende vurderinger, slik KGB-sjefen gjorde (Grossmann, 2007). Den norske regjering bør i sin overveielse av aktuelle norske sikkerhetspolitiske veivalg tenke seg i president Kennedys sted under Cuba-krisen, og bruke samme metode som ham for å få fram bedre analyser som beslutningsgrunnlag, systematisk uenighet.

Erfaringene med uenighet $\mathrm{i}$ viktige beslutninger viser at vår og andres virkelighetsforståelse er dynamisk, og dermed formbar (Kahneman, 2003; Shapiro, 2010, 2016). Det betyr sikkerhetspolitisk handlingsrom.

\section{Fra den tredje kalde krigen til felles sikkerhet}

Erfaringene fra den andre kalde krigen i første halvdel av 1980-tallet viser at det også i den pågående tredje kalde krigen er viktig å bruke det sikkerhetspolitiske handlingsrom til å redusere spenninger. Uten et klima for politiske løsninger beveger lands utenrikspolitikk seg inn en militær forestillingsverden, som i ytterste konsekvens ender i krig. Det er det vi nå ser i konflikten om Ukraina.

Men russisk politikk er ikke entydig. Militære operasjoner i Midtøsten ledsages av et omfattende diplomati som posisjonerer Russland for å mekle og forhandle en politisk løsning (RIAC \& IRAS, 2016; Fjærtoft, 2020). ${ }^{10}$ Uavhengig av hva vi ellers mener om utviklingen i Russland, er ledelsen i Kreml en nødvendig partner for å gjenreise en mer stabil internasjonal politisk orden. Det mener Henry Kissinger:

In the 1960 s and 1970 s, I perceived international relations as an essentially adversarial relationship between the United States and the Soviet Union. With the evolution of technology, a conception of strategic stability developed that the two countries could implement, even as their rivalry continued in other areas. The world has changed dramatically since then. In particular, in the emerging multipolar order, Russia should be perceived as an essential element of any new global equilibrium, not primarily as a threat to the United States. (Kissinger, 2016)

\footnotetext{
${ }^{10}$ Dette er også vurderingen til den norske Midtøsten-eksperten professor Knut Vikør: http:// knutsvblogg.blogspot.com/
} 
Hverken i Ukraina, ellers i Europa eller i Midtøsten er bærekraftige politiske løsninger nå realistiske uten russisk medvirkning. Artikkelen har tidligere påvist at dagens konfrontasjoner med Russland har likhetstrekk med konfrontasjonene med Sovjetunionen i første halvdel av 1980-tallet. Vi har sett hvordan det den gang likevel var et handlingsrom for politisk dialog $\mathrm{i}$ en krevende gråsone mellom mistenkeliggjøring, manipulering og dynamiske politiske prosesser. Datidens frykt for at østlig etterretning utnyttet den vesttyske fredsbevegelsens motstand mot NATOs nye atomvåpen for å sementere et militært overtak (Teltschik, 2019), er sammenliknbart med vår frykt i dag for russiske forsøk på manipulering av vestlige valg og meningsdannelse på sosiale medier, og en tilsvarende russisk frykt for vestlig undergraving gjennom støtte til ikke-statlige organisasjoner og folkelige opprør.

Den innsikt som nå i ettertid er mulig i de interne prosesser i DDR, som denne artikkelen har redegjort for, er derfor relevant for vestlige sikkerhetspolitiske veivalg under den tredje kalde krigen som vi nå står oppi. Lavintensiv krig i Europa, den gang kuppet i Polen i 1981, i dag krigen i Ukraina, forblir en offensiv militær opsjon som avskrekking må blokkere. Likevel er en reell risiko fortsatt at misforståelser om motstanderes hensikter kan utløse forkjøpsangrep, både med og uten atomvåpen. Vestlig språkbruk og opprustning, selv med legitime og rasjonelle mål, kan få som utilsiktet virkning å øke krigsfare, også for atomkrig. Derfor må vestlig sikkerhetspolitikk i dag forholde seg til hvordan Russland ser verden. I likhet med Sovjetunionen i første halvdel av 1980-tallet mener Kreml fremdeles at deres egne offensive opsjoner har et defensivt formål. Det er den mest sannsynlige beveggrunn for lavintensiv militær agering i Ukraina, Syria og Libya.

Russland ser behov for å demme opp for det de ser som en ekspansiv rolle for NATO som redskap for USAs politikk, herunder at vestlig militærmakt brukes til regimeskifter (RIAC \& IRAS, 2016; McFaul, 2018; Perry, 2015). Det betyr ikke at russisk politikk hverken er legitim eller uproblematisk, men for å snu den utvikling vi nå er inne i med eskalerende konflikter og en tiltakende militær tankegang på begge sider, må vestlig analyse av sikkerhetspolitiske veivalg legge til grunn at Russland følger sine egne mentale modeller, ikke våre (Heuer, 1999; Kahneman, 2003). En bedre sikkerhetspolitisk analyse vil føre til sikkerhetspolitiske veivalg med bedre prognose for tilsiktede virkninger enn dagens konfrontasjoner og opprustning.

En mer nøktern sikkerhetspolitisk analyse både i NATO og Russland vil vise at en mental modell med felles sikkerhet, $\mathrm{i}$ tråd med Egon Bahrs tankegang og Palme-kommisjonen fra 1982, er i felles interesse. Etter slutten på den andre kalde krigen i 1989 samarbeidet Russland og USA om å fjerne gamle sovjetiske atomvåpen fra de nye statene som oppstod etter Sovjetunionens oppløsning (Perry, 2015). I senere år samarbeidet USA og Russland om å fjerne kjemiske våpen fra Syria og hindre Iran i å utvikle atomvåpen (Fjærtoft, 2019b).

Vi har sett hvordan militære strategier er tankekonstruksjoner om imaginære konsekvenser. De formidles gjennom vårt språk som symbolske univers (Berger 
\& Luckmann, 1991). Tankekonstruksjonene er dynamiske og kan endres gradvis gjennom en målbevisst språklig formidling av alternative tankekonstruksjoner, en ny diskurs. Derfor er første skritt mot en ny felles sikkerhet i Europa å begynne å tale vedvarende om felles sikkerhet som en alternativ visjon til konfrontasjoner og våpenkappløp.

Et norsk initiativ for felles sikkerhet i Europa i dag ville være å slutte seg til FNs totalforbud mot atomvåpen. Nettopp i dagens politiske klima kan Norge med et slikt skritt formidle tydelig en alternativ tankekonstruksjon, en visjon om endelig avskaffelse av atomvåpen. En slik visjon har, som vi har sett, bred støtte blant politikere og eksperter med full innsikt i alle sider ved atomvåpen.

Men Norge kan ikke alene endre sikkerhetspolitiske rammebetingelser. Norske initiativ trenger ryggdekning blant nærstående land for å få gjennomslag. Forholdet til USA vil stå sentralt i både norske og nærstående lands vurderinger. Spørsmålet om tilslutning til FNs totalforbud mot atomvåpen henger derfor nøye sammen med en nøktern prognose for utviklingen av USAs sikkerhetspolitiske adferd.

\section{Er ryggdekning hos USA realistisk og nødvendig for å slutte seg til FNs totalforbud mot atomvåpen?}

USAs utenriks- og sikkerhetspolitikk er fremdeles i første rekke drevet av amerikansk innenrikspolitikk, der utenlandske fiendebilder forener ellers splittede interne koalisjoner. Også under president Biden sørger mektige forretningsinteresser for et vedvarende press på medlemmer av Kongressen for høyt rustningsnivå. Kongressen presser presidenten. Russisk og europeisk motstand øker den innenrikspolitiske symbolverdien av opprustning og konfrontasjoner. De rådende indrepolitiske forhold i USA vil ventelig føre til en fortsatt internasjonal opptreden med inflasjon i sanksjoner.Vi kan også fortsatt forvente plutselige militærangrep, særlig i Midtøsten, men kanskje også andre steder.

Så langt er de sikkerhetspolitiske signaler fra Biden blandede. USA støtter igjen viktige internasjonale avtaler, også avtalen med Iran som hindrer iranske atomvåpen, den kanskje viktigste rustningskontrollavtalen på grunn av de ustabile forhold i Midtøsten (Mathews, 2021). På den annen side ser vi en ideologisk tilnærming som åpenbart medfører en risiko for eskalering av konflikter. Særlig Bidens utenriksminister Blinken synes å mene at andre land skal innordne seg USAs ledelse av verden gjennom konfrontasjoner med stater USA anser som fiender. Norges naboland Russland er blant dem.

USAs selvforståelse som rollemodell og moralsk verdensleder betyr sannsynligvis også under president Biden en risiko for feilvurderinger. Dessuten er det usikkert hvor lenge demokratene vil beholde makten i Kongressen. Republikanske politikere frykter med god grunn Trumps velgere, og mektige organiserte pressgrupper arbeider systematisk for å endre valgordninger for å ekskludere 
demokratiske velgere. President Bidens etter måten opplyste regime kan lett bli en kort parentes mellom ekstreme republikanske regimer, i Det hvite hus, i Kongressen og i delstatene.

En nøktern risikoanalyse av utviklingen i USA bør føre til at Europa i EU opptrer selvstendig fra USA også i sikkerhetspolitiske spørsmål, slik det allerede skjer i handelspolitikk og miljøpolitikk. Objektive kriterier som befolkning og BNPstørrelse viser at Europa i EU ikke trenger å være avhengig av USA i sikkerhetspolitiske spørsmål. EU med Norge har dessuten sterkere politiske tradisjoner enn USA for internasjonalt samarbeid. Uten USA kan nærstående europeiske land innlede en pragmatisk dialog med Russland om en felles europeisk sikkerhet. Historiske erfaringer viser at det er i et politisk klima med lavspenning at politiske stridsspørsmål lar seg løse.

Dersom den norske regjering tar et politisk initiativ til en europeisk prosess for felles sikkerhet ved å slutte seg til FNs totalforbud mot atomvåpen, vil et slikt skritt ventelig utløse protester fra USA og kanskje de europeiske atomvåpenmakter, Storbritannia og Frankrike, men neppe noen umiddelbare dramatiske endringer i Norges sikkerhet. En ryggdekning for norsk tilslutning til FNs totalforbud mot atomvåpen kan derfor komme etter at Norge støtter forbudet. Ryggdekning for et slikt initiativ bør Norge skaffe seg gjennom en felles politisk prosess med EU-land, særlig de nordiske land og Tyskland. Som eneste nordiske land stemte Sverige for FNs totalforbud mot atomvåpen. Norge kan derfor stå sammen med vårt mest nærstående land $i$ et felles initiativ overfor likesinnede europeiske land.

\section{Konklusjon}

Den norske regjering bør slutte seg til FNs totalforbud mot atomvåpen og sammen med Sverige, som stemte for avtalen i FN, ta et initiativ overfor andre nærstående europeiske land til et europeisk forsvar uten atomvåpen.

Europa bør uavhengig av USA innlede en politisk dialog med Russland om felles europeisk sikkerhet. En slik dialog vil redusere spenninger, og dermed skape et politisk klima som giør det mulig å løse stridsspørsmål som nå eskalerer konflikter. Europa er med sitt folketall, sin økonomi og sitt industrielt-teknologiske nivå en likeverdig partner for Russland. Med tilstrekkelig forsvar på lavest mulig nivå kan Europa blokkere russiske opsjoner, som press, undergraving og lavintensive militære operasjoner.

Alle representanter i en sikkerhetspolitisk dialog og i forhandlinger må sikre seg ryggdekning i eget regime. Derfor må en sikkerhetspolitisk dialog med Russland begrense seg til forslag som alle parter ser øker deres sikkerhet. Utenforliggende stridsspørsmål, som i dag blokkerer en sikkerhetspolitisk dialog med Russland, må utsettes til en forståelse av felles sikkerhet gjør det mulig å finne løsninger. 


\section{Om forfatteren}

Torgeir E. Fjærtoft er norsk diplomat med erfaring fra USA, Tyskland, FN, EU og Midtøsten. Han var tidligere gjesteforsker fra UD ved Senter for islam- og midtøstenstudier, Oslo, og Institutt for samtidshistorie, Avdeling for den kalde krigen, Berlin. Fiærtoft er nå forsker og analytiker i UD med sitt forskningsprosjekt "Common Security Project”. E-post: tef@commonsecurity.no.

\section{Referanser}

Allison, G. T. \& Zelikow, P. (1999). Essence of decision: Explaining the Cuban Missile Crisis. Longman.

Aronoff, Y. S. (2014). The political psychology of Israeli prime ministers: When hard-liners opt for peace. Cambridge University Press.

Bahr, E. (1996). Zu meiner Zeit. Siedler.

Bahr, E. (2012). Ostwärts und nichts vergessen! Kooperation statt Konfrontation. Verlag Hamburg.

Bahr, E. (2013). "Das musst du erzählen «: Erinnerungen an Willy Brandt. Propyläen Verlag.

Berger, P. L. \& Luckmann, T. (1991). The social construction of reality: A treatise in the sociology of knowledge. Penguin Books Limited.

Bondevik, K. M., Jagland, T., Strøm-Erichsen, A.-G., Løwer, E., Vollebæk, K. \& Godal, B. T. (2020, 21. september). Vi kan ikke overlate denne risikoen til våre barn og barnebarn. Forby atomvåpen nå! [Kronikk]. Aftenposten. https:/www.aftenposten.no/meninger/kronikk/i/dldk5J/vi-kan-ikke-overlate-dennerisikoen-til-vaare-barn-og-barnebarn-forby

Brandt, W. (2013). Erinnerungen (1. utg.). List, Ullstein Buchverlage GmbH.

Bundy, M. G. (1988). Danger and survival: Choices about the bomb in the first fifty years. Random House Publishing Group.

Carter, A. B. et al. (1987). Managing nuclear operations. Brookings Institution.

Clark, C. M. (2012). The sleepwalkers: How Europe went to war in 1914. Allen Lane.

Etterretningstjenesten. (2021). Fokus 2021: Etterretningstjenestens vurdering av aktuelle sikkerhetsutfordringer. https:/www.forsvaret.no/aktuelt-og-presse/publikasjoner/fokus

Fischer, B. B. (1997). A Cold War conundrum: The 1983 Soviet war scare. Central Intelligence Agency, Center for the Study of Intelligence.

Fjærtoft, T. E. (2019a). Engaging the US in the age of Trump:The case for a new European strategic discourse. European Foreign Affairs Review, 24(1), 7-26.

Fjærtoft, T. E. (2019b). From the fall of the Berlin Wall to the fall of Aleppo. The decline of global governance and how to restore it. Global Policy. https://doi.org/10.1111/1758-5899.12736

Fjærtoft, T. E. (2020). Envision, not argue: Innovating EU policy after the failures of Libya and Syria. European Foreign Affairs Review, 25(1), 61-78.

Forsvarsdepartementet \& Utenriksdepartementet. (2018). Libya-rapporten: Evaluering av norsk deltakelse $i$ Libya-operasjonen. https://www.regjeringen.no/no/dokumenter/libya-rapporten/id2610845/

Freedman, L. (2015a). The possibilities and limits of strategic narratives. I B. D. Graaf, G. Dimitriu \& J. Ringsmose (Red.), Strategic narrative, public opinion, and war (s. 17-37). Routledge.

Freedman, L. (2015b). Strategy: A history. Oxford University Press.

Gaddis, J. L. (2018). On grand strategy. Penguin Books Limited.

Grossmann, W. (2007). Bonn im Blick: die DDR-Aufklärung aus der Sicht ihres letzten Chefs. Das Neue Berlin.

Hellestveit, C. \& Egeland, K. (2020). Nato, Norge og kjernevåpen. Folkerettsinstituttet. http://intlaw.no/ publikasjoner/rapporter/ny-rapport-nato-norge-og-kjernevapen/

Heuer, R. J. (1999). Psychology of intelligence analysis. Center for the Study of Intelligence.

Hoffman, D. E. (2010 (2009)). The dead hand. Reagan, Gorbachev and the untold story of the Cold War arms race. Icon Books Ltd.

Jervis, R. (2017). Perception and misperception in international politics (2. utg.). Princeton University Press.

Kahneman, D. (2003). Maps of bounded rationality: Psychology for behavioral economics. The American Economic Review, 93(5), 1449-1475.

Kahneman, D. \& Renshon, J. (2007). The hawk bias. Foreign Policy, 158, 32-36. 


\section{Norsk støtte til FNs totalforbud mot atomvåpen?}

Kalinovsky, A. (2009). Decision-making and the Soviet war in Afghanistan. From intervention to withdrawal. Fournal of Cold War Studies, 11(4), 46-73.

Kennedy, R. F. \& Schlesinger, A. M. (2011). Thirteen days: A memoir of the Cuban Missile Crisis. W. W. Norton.

Kissinger, H. (1973). A world restored: Metternich, Castlereagh, and the problems of peace, 1812-22. Houghton Mifflin.

Kissinger, H. (2016, 4. februar). Kissinger's visions for U.S.-Russia relations. The National Interest. https:// nationalinterest.org/feature/kissingers-vision-us-russia-relations-15111

Kubiczek, W., Romberg, W., Scheler, W., Schreiber, W., Schwarz, W. \& Thielicke, H. (2014). Neues Denken in der DDR. Konzepte zur Sicherheit in Europa in den 1980er Fahren. WeltTrends.

Mathews, J. T. (2021, 27. mai). Losing no time. The New York Review. https://www.nybooks.com/articles/ 2021/05/27/losing-no-time-biden-first-100-days/

McFaul, M. (2018). From Cold War to hot peace: An American ambassador in Putin's Russia. Houghton Mifflin Harcourt.

McNamara, R. S. (2009, 21. oktober). Apocalypse soon. Foreign Policy.

Merseburger, P. (2013). Willy Brandt: 1913-1992.Visionär und Realist. Pantheon.

Pelopidas, B. (2015). A bet portrayed as a certainty: Reassessing the added deterrent value of nuclear weapons. I G. P. Schultz \& J. E. Goodby (Red.), The war that must never be fought: Dilemmas of nuclear deterrence. The Hoover Institution.

Perry, W. (2015). My journey at the nuclear brink. Stanford University Press.

Plokhy, S. (2021). Nuclear folly: A new history of the Cuban missile crisis. Penguin Books Limited.

Preston, A. (2010). The war council: McGeorge Bundy, the NSC, andVietnam. Harvard University Press.

Price, R. (2019). Syria and the chemical weapons taboo. Fournal of Global Security Studies, 4(1), 37-52. https:// doi.org/10.1093/jogss/ogy040

Pry, P. V. (1999). War scare: Russia and America on the nuclear brink. Praeger.

Reuters. (2021, 16. mars). Britan to expand nuclear warhead stockpile by over $40 \%$ as global threats rise. https:// www.reuters.com/article/uk-britain-politics-nuclear-weapons-idUSKBN2B81N4

RIAC \& IRAS. (2016). Russia-Iran partnership: An overview and prospects for the future. Russian International Affairs Council, Moscow, The Institute for Iran-Eurasia Studies.

Savaranskaya, S. V. (2005). New sources on the role of Soviet submarines in the Cuban Missile Crisis. The Fournal of Strategic Studies, 28(2), 233-259. https://doi.org/10.1080/01402390500088312

Schild, G. (2013). 1983: Das gefährlichste Fahr des Kalten Krieges. Schöningh.

Senge, P. M. (1994). The fifth discipline fieldbook: Strategies and tools for building a learning organization. Currency, Doubleday.

Shanker, T. \& Landler, M. (2007, 11. februar). Putin says U.S. is undermining global stability. New York Times. https:/www.nytimes.com/2007/02/11/world/europe/11 munich.html

Shapiro, D. L. (2016). Negotiating the nonnegotiable: How to resolve your most emotionally charged conflicts. Penguin Publishing Group.

Shapiro, D. L. (2010). Relational identity theory. A systematic approach for transforming the emotional dimension of conflict. American Psychologist, 68(7), 634-645. https://doi.org/10.1037/a0020004

Shultz, G. P. \& Goodby, J. E. (2015). The war that must never be fought: Dilemmas of nuclear deterrence. Hoover Institution Press.

Shultz, G. P., Perry, W. J., Kissinger, H. A. \& Nunn, S. (2007-2011). Toward a world without nuclear weapons. https://media.nti.org/pdfs/NSP_op-eds_final_.pdf

Simon, H. A. (2013). Administrative behavior (4. utg.). Free Press.

Teltschik, H. (2019). Russisches Roulette:Vom Kalten Krieg zum Kalten Frieden. C.H. Beck.

Tzu, S., Zi, S. \& Giles, L. (2006). The art of war. Filiquarian Publishing, LLC.

Wolf, M. (2003). Spionagechef im geheimen Krieg: Erinnerungen. Ullstein.

Woodward, B. (2010). Obama's wars. Simon \& Schuster. 


\begin{abstract}
English
Norwegian Support for the UN's Total Ban on Nuclear Weapons?

The article argues that while the UN ban on nuclear arms is obviously sensible, the Norwegian Government's objections are still rational. Rejecting the US nuclear arms umbrella undermines deterrence to the degree that is the perception. The article sets out how cognitive processes determine perceptions of deterrence and risks of war. Shifting nuclear strategies are attempts to cope with the contradiction between deterrence and the inherent impossible choice of nuclear war. The Cold War in the first half of the 1980s shows how nuclear arms, though intended as deterrence, in a confrontation may be misperceived as a looming attack. This misperception almost caused nuclear war by inadvertence, as it could again. The fear of attack may prompt a compelling sense of urgency for a preemptive strike. This is the only real risk of large-scale war in Europe. Therefore, the Norwegian Government should join the UN ban on nuclear arms to reduce tensions in Europe. In a joint initiative with Sweden, which has already endorsed the ban, Norway should persuade other European states to enable a political process with Russia towards a European common security without the looming threat of nuclear arms. Military force should not exceed the minimum required to block intimidation, coercion, and lowintensity aggression.
\end{abstract}

Keywords: nuclear arms $\cdot$ deterrence $\cdot$ security $\cdot$ dialogue 